\title{
The Oxygen Reduction Activity of Pt-Mn/C and Pt-Cu/C Alloys
}

Mohammadreza Zamanzad Ghavidel, E. Bradley Easton*

Electrochemical Materials Lab, Faculty of Science, Ontario Tech University ${ }^{l}$, 2000 Simcoe Street N, Oshawa, ON, Canada

*Corresponding author: E-mail: Brad.Easton@uoit.ca;

\begin{abstract}
Pt-Mn and Pt-Cu alloys with low Pt contents have been previously shown to be highly active for the ethanol oxidization reaction. Here we examined these alloys for their activity towards the oxygen reduction reaction (ORR) in acidic media. The ORR activity of these alloys has also compared to the $\mathrm{Pt} / \mathrm{C}$ and $\mathrm{Pt}-\mathrm{Sn} / \mathrm{C}$ commercial samples. In addition, the effect of heat treatment and formation of ordered structures on the ORR activity in both $\mathrm{Pt}-\mathrm{Cu}$ and $\mathrm{Pt}-\mathrm{Mn}$ systems were investigated. The highest $\mathrm{V}_{\text {on-set }}$ was recorded for $\mathrm{Pt} / \mathrm{C}$. While adding the alloying elements may slightly reduce the ORR activity, these catalysts had no more that $25 \mathrm{at} \% \mathrm{Pt}$, which is promising from a cost stand point. In addition, our findings show that the heat treatment and formation of ordered phases had a great impact on the ORR activity of the alloyed samples.
\end{abstract}

Keywords: Pt-Cu alloy; Pt-Mn alloy; oxygen reduction reaction; fuel cells

\footnotetext{
${ }^{1}$ Formerly known as University of Ontario Institute of Technology
} 
M. Zamanzad Ghavidel, E.B. Easton, ECSarXiv (2019) doi: 10.1149/osf.io/ja9k4.

\section{Introduction}

In last few decades, great number of studies have focused on developing catalysts for improving the oxygen reduction reaction (ORR) in fuel cells [1-6]. It is well known that ORR suffers from large overpotentials and thus limits the overall performance of fuel cells [3]. In addition, in direct alcohol fuel cells (DAFCs) slow kinetics of the alcohol (ethanol or methanol) reduction along with sluggish ORR behaviour could reduce the performance of the DAFC dramatically [6-10]. Therefore, in addition to synthesising very active catalysts for anodic reaction, it is essential to develop new catalysts which are improving ORR activities. Pt is the most commonly used electrocatalyst for both cathodic and anodic reaction in the commercial fuel cells. Pt is an expensive element and the efforts to reduce Pt and other noble metal contents in fuel cells are challenging [11-14]. On the other hand, the new non-noble metal catalysts have shown a low mass activity in fuel cells $[3,15,16]$. As a result, developing alloy catalysts that have lower Pt contents are more appealing due to proven high activity of the Pt-alloy catalysts toward oxygen reduction [17-24]. In addition, it has been shown that the Pt-alloys can be effective to reduce the costs and increase the efficiency of DAFCs $[7,9,11,25]$.

The ORR activity enhancement in the presence of alloying elements could be due to: (i) variation in $\mathrm{Pt}-\mathrm{Pt}$ bond distances (ii) inhibition of $\mathrm{OH}_{\text {ads }}$ adsorption (iii) formation of the metal particles with rougher surface because of surface oxide or alloying element dissolution (iv) changes in the electronic structure and formation of greater number of Pt d-band vacancies [3, 4]. Therefore, the ORR activity of supported catalysts could be altered by particle size, shape, composition, supporting material and method of preparation [3, 4]. Different Pt-alloys have been examined in order to improve ORR activity [19-22, 24, 26-30]. One study on different PtM alloys $(\mathrm{M}=\mathrm{Cr}, \mathrm{Mn}, \mathrm{Co}, \mathrm{Ni})$ on carbon supports has shown that the ORR limiting current has exhibited Volcano plot versus the electronic (d-band vacancy) and geometric (Pt-Pt distance) factors and the Pt-Cr alloy have reported as the most active sample [31]. Another study on sputtered $\mathrm{Pt}_{3} \mathrm{M}(\mathrm{M}=\mathrm{Ni}, \mathrm{Co}, \mathrm{Fe}, \mathrm{V}, \mathrm{Ti})$ alloys has illustrated that an optimal catalytic activity will achieved when there is balance between the energy of reactive intermediate adsorption and desorption of blocking species. In this case, $\mathrm{Pt}_{3} \mathrm{Co}$ has shown the highest activity compared to other alloyed samples [2]. Studies on $\mathrm{Pt}-\mathrm{Sn} / \mathrm{C}, \mathrm{Pt}-\mathrm{Ni} / \mathrm{C}$ and $\mathrm{Pt}-\mathrm{Sn}-\mathrm{Ni} / \mathrm{C}$ also have shown that the ORR activity of samples in the presence of alloying element have improved and the Pt-Sn alloy 
have resulted in the highest mass activity [19]. In addition, it has been indicated that Sn oxide phases facilitate ORR [28, 29, 32].

Recent studies have revealed that Pt-Cu are also very good candidate for ORR [12, 22-24, 27, 30, 33, 34]. Pt-Cu nanoparticles with Pt rich surface have shown that the presence of $\mathrm{Cu}$ modified the electronic properties of Pt atoms on the surface and enhanced the ORR activity [23]. Different Pt-M ( $\mathrm{M}=\mathrm{Au}, \mathrm{Pd}$, or $\mathrm{Cu}$ ) nanorods have also been studied, with $\mathrm{Pt}-\mathrm{Cu}$ nanorods displaying the highest ORR activity [24]. Tseng et al.[30] used both the impregnation and polyol methods to produce Pt-Cu alloys and studied the effect of heat treatment on the ORR activity of the Pt-Cu particles. Their findings have illustrated that the polyol method and the heat treatment at $300{ }^{\circ} \mathrm{C}$ in a hydrogen atmosphere caused the ORR activity enhancement. In addition, it has been shown that heat treatment and formation of the ordered Pt-Cu alloys could improve the stability and the ORR activity due to better retention of the copper inside the ordered structure [27].

The Pt-Mn and Pt-Cu alloy system has recently been identified by our group as having enhanced activity towards the ethanol oxidation reaction (EOR) [35-38]. Alloy formation was confirmed with X-ray powder diffraction (XRD) analysis, and the most active alloys contained less than $25 \mathrm{at} \% \mathrm{Pt}$, which is beneficial from a cost standpoint. In addition, it have shown that presence of $\mathrm{Cu}$ as a ternary alloying element enhanced the activity of the Pt-Mn alloys toward EOR [36]. However, the impregnation method usually results in a mixture of weakly alloyed samples and a high degree of agglomeration which makes it difficult to gain a solid conclusion on the catalytic activity of samples [35-39]. Our studies showed that post-heat treatment had a great impact on the activity of the Pt-Mn and Pt-Cu alloys, and the main reason for enhancing the EOR activity was the formation of the PtMn and $\mathrm{PtCu}$ intermetallic phases [40].

While there have been a few studies of ordered heat treated Pt-Cu systems [13, 20, 22, 27, 41], there are very limited studies of the heat treated Pt-Mn systems [13, 42]. The heat treatment and structural ordering process could significantly affect the ORR activity of Pt-Mn and Pt-Cu systems, due to particle size growth and formation of new alloy phases [1, 22, 40, 43]. The particle size growth during heat treatment is an unwanted consequence. Sintering can happen by the migration and coalescence of the catalyst particles or by evaporation and condensation of the atoms from small crystallites [1]. However, the impact of structural ordering along with particle 
growth on the ORR activity in Pt-Cu and Pt-Mn systems are poorly studied, especially for the PtMn alloys.

Here the ORR activity of the Pt-Mn and Pt-Cu samples was studied in detail. The most active and stable samples in both Pt-Mn and Pt-Cu systems were selected based on our previous studies $[40,44]$ and were tested using a rotating ring-disc electrode (RRDE) in oxygenated solution. The ORR activity of these alloys has compared to different commercially available samples (Pt/C and $\mathrm{Pt}-\mathrm{Sn} / \mathrm{C}$ ). Finally, the effects of heat treatment and formation of ordered structures in both Pt-Cu and Pt-Mn systems were investigated.

\section{Experimental}

\subsection{Catalyst Synthesis}

The carbon supported Pt-Mn and Pt-Cu alloys were prepared as per our previous reports [40, 44, 45]. Impregnation in the presence of sodium citrate (SC) was used for Pt-Mn/C samples and microwave assisted polyol method used for the $\mathrm{Pt}-\mathrm{Cu} / \mathrm{C}$ samples. In addition, two commercial control samples Pt/C (Premetek Co.) and Pt-Sn/C (Premetek Co.) were studied and compared to the samples made in-house. These samples are hereafter referred to as Pt-Mn/C-SC, Pt-Cu/C-POL, $\mathrm{Pt} / \mathrm{C}$ and $\mathrm{Pt}_{3} \mathrm{Sn} / \mathrm{C}$, respectively. The target composition was of $\mathrm{Pt}_{0.25} \mathrm{M}_{0.75} / \mathrm{C}(\mathrm{M}=\mathrm{Mn}$ and $\mathrm{Cu})$. This composition was chosen based on our group previous studies [38] and recently published articles [27, 46-48]. Metal precursors were $\mathrm{H}_{2} \mathrm{PtCl}_{6} \cdot \mathrm{H}_{2} \mathrm{O}$ (Aldrich), $\mathrm{MnCl}_{2} .4 \mathrm{H}_{2} \mathrm{O}$ (Aldrich), and $\mathrm{CuCl}_{2} 2 \mathrm{H}_{2} \mathrm{O}$ (Aldrich). Vulcan XC72R carbon black (Cabot Corp.) was used as the carbon support in all cases. The total metal loading was targeted as $\sim 20 \mathrm{wt} \%$ for all samples. The $\mathrm{pH}$ of the reaction solution was adjusted using a $\mathrm{HCl}$ solution $(15 \mathrm{v} / \mathrm{v} \%)$ and/or a $1 \mathrm{M} \mathrm{NaOH}$ solution. For the impregnation method with the additive, Trisodium Citrate (SC) (Aldrich) was added in a weight ratio of 2:1 to the metal ratios. $\mathrm{NaBH}_{4}$ powder was used as a reduction agent. The weight ratio of $\mathrm{NaBH}_{4}$ to the metal content was $3: 1$. The $\mathrm{pH}$ of the solution was adjusted to 3 for the impregnation method. For the polyol method, the metal precursors and Vulcan carbon were mixed with ethylene glycol (EG) (Aldrich) using a mechanical stirrer. The solution $\mathrm{pH}$ was adjusted to $\mathrm{pH} 9$, after which it was sonicated for $45 \mathrm{~min}$ to achieve a uniform suspension. The suspension was placed into the household microwave oven (SANYO - $2450 \mathrm{MHz}$ ) and heated for 8 min and then left to cool down under continues mechanical stirring. In all the methods, the resulting powder was filtered and 
washed with isopropanol alcohol (IPA), acetone, and deionized water, and finally dried in an oven at $80{ }^{\circ} \mathrm{C}$ overnight.

The selected samples were heat treated in a nitrogen atmosphere at $700{ }^{\circ} \mathrm{C}$ in a Barnstead Thermolyne tube furnace with a quartz tube. The period of heat treatment was kept constant $(1 \mathrm{~h})$ for all the samples. The heat treatment time and temperature was also chosen base on previous studies by our group [39]. After the heat treatment, the samples were cooled down under a constant flow of nitrogen gas and were preserved inside the furnace until room temperature was reached.

\subsection{Electrochemical Measurements}

Electrochemical measurements a Pine WaverDriver 20 bipotentiostat/galvanostat. Linear sweep voltammograms (LSVs) were obtained for each set of samples without any rotation in a $\mathrm{N}_{2}$-purged $0.5 \mathrm{M} \mathrm{H}_{2} \mathrm{SO}_{4}$ solution to determine the background due to the Vulcan carbon particles. Following the background test, LSVs were recorded to evaluate ORR in a $0.5 \mathrm{M} \mathrm{H}_{2} \mathrm{SO}_{4}$ solution saturated with pure $\mathrm{O}_{2}$ gas for $15 \mathrm{~min}$. LSV was repeated at five different rotation rates: $200 \mathrm{rpm}$, $400 \mathrm{rpm}, 900 \mathrm{rpm}, 1600 \mathrm{rpm}$, and $2500 \mathrm{rpm}$, starting from the highest rpm. The limiting current and onset potentials were determined and compared at a rotation rate of $1600 \mathrm{rpm}$ unless otherwise specified. The limiting current is determined from the point at which the measurements plateau $(0.332 \mathrm{mV}$ vs NHE) and the onset potential is defined as the potential at $5 \%$ of the limiting current. The RRDE collection experiments were utilized to study the hydrogen peroxide production $\left(\mathrm{H}_{2} \mathrm{O}_{2}\right)$. The ring potential was held at $1.2 \mathrm{~V}$ to oxidize any evolved $\mathrm{H}_{2} \mathrm{O}_{2}$.

\subsection{Thermal Analysis}

Thermogravimetric analysis (TGA) was performed using a TA Instruments Q600 SDT system. Measurements were made in an argon atmosphere using a heating ramp of $20^{\circ} \mathrm{C} / \mathrm{min}$.

\section{Results and Discussion}

Figure 1 shows the thermogravimetry (TG) and derivative thermogravimetry (DTG) curves obtained for the Pt-Cu/C-POL samples. The mass loss occurring between $100{ }^{\circ} \mathrm{C}$ and $150{ }^{\circ} \mathrm{C}$ was attributed to the thermal decomposition of functional groups on carbon and the evaporation of any residual water in the samples $[49,50]$. The mass loss detected between 150 and $250^{\circ} \mathrm{C}$ was 
due to removal of the trace of ethylene glycol or other contamination which still remain in the structure of the catalyst powder and was not removed during the washing process. This temperature is very close to the boiling temperature of EG $\left(197.3^{\circ} \mathrm{C}\right)$. The third major mass loss was observed around $300{ }^{\circ} \mathrm{C}$, which was attributed to the oxidation of the carbon support by oxygen or the air trapped within the powdered samples [50]. Comparing the DTG diagrams of $\mathrm{Pt}-\mathrm{Cu} / \mathrm{C}-\mathrm{POL}$ and $\mathrm{Pt}-\mathrm{Cu} / \mathrm{C}-\mathrm{POL}-700{ }^{\circ} \mathrm{C}$ shows that after the heat treatment the peaks lower than $250{ }^{\circ} \mathrm{C}$ was completely removed. This indicated that the heat treatment reduced the amount of contamination and removed any ethylene glycol was existed in the catalysts structure.

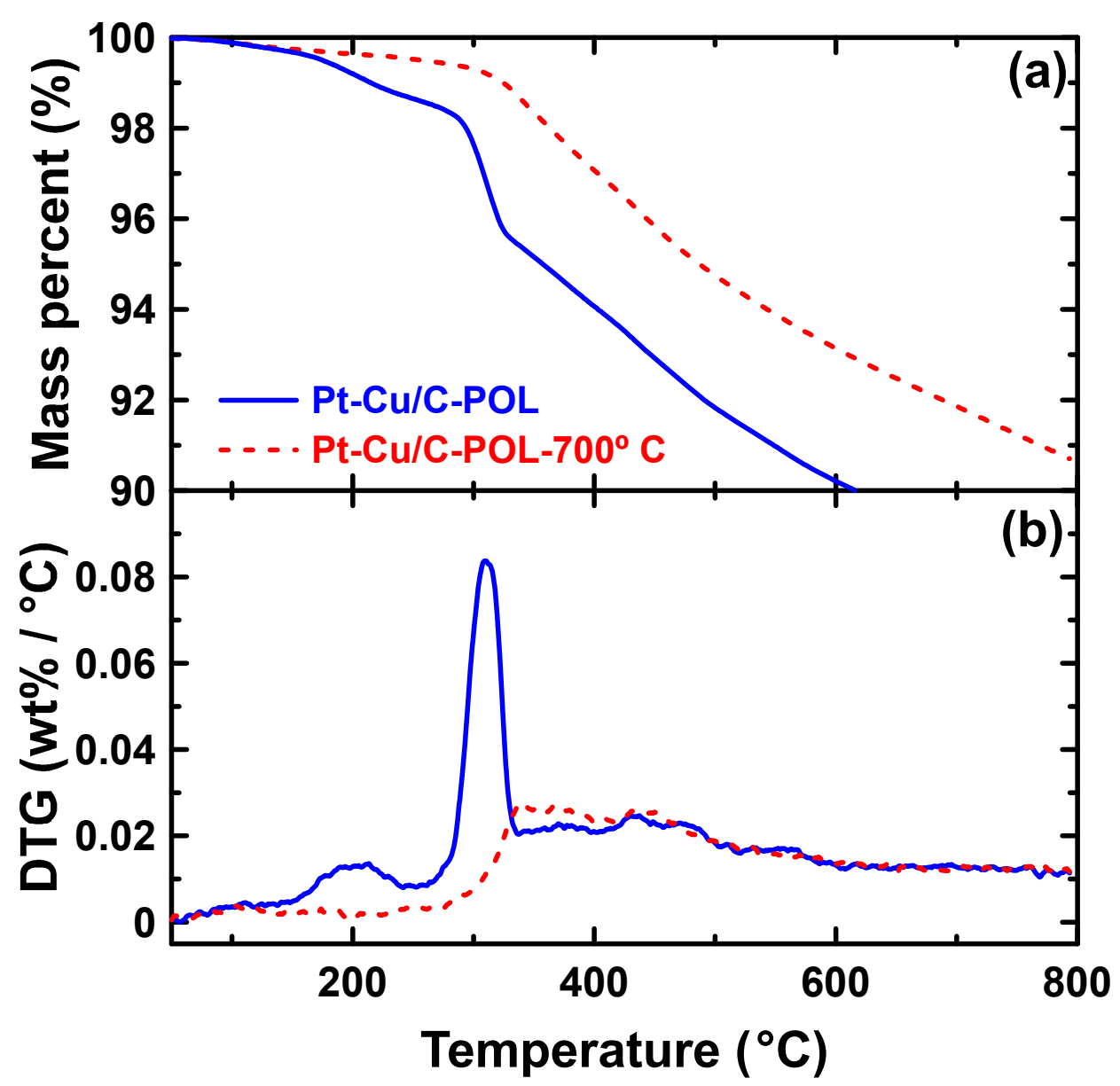

Figure 1: (a) The weight loss and (b) derivative weight loss versus temperature for $\mathrm{Pt}-\mathrm{Cu} / \mathrm{C}$ POL and Pt-Cu/C-POL- $700{ }^{\circ} \mathrm{C}$. Measurements were made at a heating rate of $20{ }^{\circ} \mathrm{C} / \mathrm{min}$ under flowing argon.

Figures 2, 3 and 4 show LSVs recorded for the Pt, $\mathrm{Pt}_{3} \mathrm{Sn}, \mathrm{Pt}-\mathrm{Mn} / \mathrm{C}$ and $\mathrm{Pt}-\mathrm{Cu} / \mathrm{C}$ samples in oxygen saturated solution. LSVs curves displayed the typical activation polarization and 
diffusion limited current as well as mixed kinetic/diffusion polarization for oxygen reduction. The limiting current density ( $\mathrm{jL}$ ) was measured at the end of each scan $(0.332 \mathrm{mV}$ vs NHE) at different rotating speeds and used to plot the Koutecky-Levich diagram. The limiting current is a combination of diffusion current $(\mathrm{jD})$ and kinetic current $(\mathrm{jK})$, but it is controlled mainly by diffusion of $\mathrm{O}_{2}$. The limiting current measured by a rotating disc experiment is described by the Koutecky-Levich equation $[3,19]$ :

$$
\frac{1}{j_{L}}=\frac{1}{j_{K}}+\frac{1}{j_{D}}
$$

Equation 3-1

jD is defined by Levich equation:

$$
j_{D}=0.62 n F D^{2 / 3} \omega^{1 / 2} v^{-1 / 6} C=\beta \omega^{1 / 2}
$$

In this equation, $\mathrm{n}$ is the average number of electrons transferred, $\mathrm{F}$ is the Faraday constant ( $96485 \mathrm{C} / \mathrm{mol}), \mathrm{D}$ is the diffusion coefficient of oxygen $\left(1.93 \times 10^{-5} \mathrm{~cm}^{2} / \mathrm{s}\right), \omega$ is the angular velocity $(\mathrm{rad} / \mathrm{s}), v$ is the kinematic viscosity of the solution $\left(0.01 \mathrm{~cm}^{2} / \mathrm{s}\right)$ and $\mathrm{C}$ is the concentration of $\mathrm{O}_{2}$ dissolved in the electrolyte $\left(1.10 \times 10^{-6} \mathrm{~mol} / \mathrm{cm}^{3}\right)[15,16]$. This equation can be written in short form as shown inEquation 3-2. If jD in Equation 3-1 is replaced by Equation 3-2, a plot of $\mathrm{jL}_{\mathrm{L}}^{-1} \mathrm{vs} \omega^{-1 / 2}$ at a fixed potential yields a straight line with the slope of $1 / \beta$, which is called Koutecky-Levich (K-L) plot. The slope can be used to predict the average number of electrons transferred due to the oxygen reduction. The K-L plots are shown in Figure 5 for different samples and the slope calculated are presented in Table 1.

In Figure 2, the ORR activity of two commercial samples are compared. The on-set potential $\left(\mathrm{V}_{\text {on-set }}\right.$ ) and limiting current for the rotating speed of $1600 \mathrm{rpm}$ are reported in Table 1 . The onset potential and $\mathrm{j}_{\mathrm{L}}$ for $\mathrm{Pt}_{3} \mathrm{Sn}$ were reduced slightly compared to $\mathrm{Pt} / \mathrm{C}$. This indicates that adding Sn to the Pt structure marginally reduced the ORR activity. However, by considering the reduction of the $\mathrm{Pt}$ loading, it can be concluded that $\mathrm{Pt}_{3} \mathrm{Sn}$ is a good candidate to replace the $\mathrm{Pt} / \mathrm{C}$ catalyst on the cathode side, especially for the sensing application. 
M. Zamanzad Ghavidel, E.B. Easton, ECSarXiv (2019) doi: 10.1149/osf.io/ja9k4.

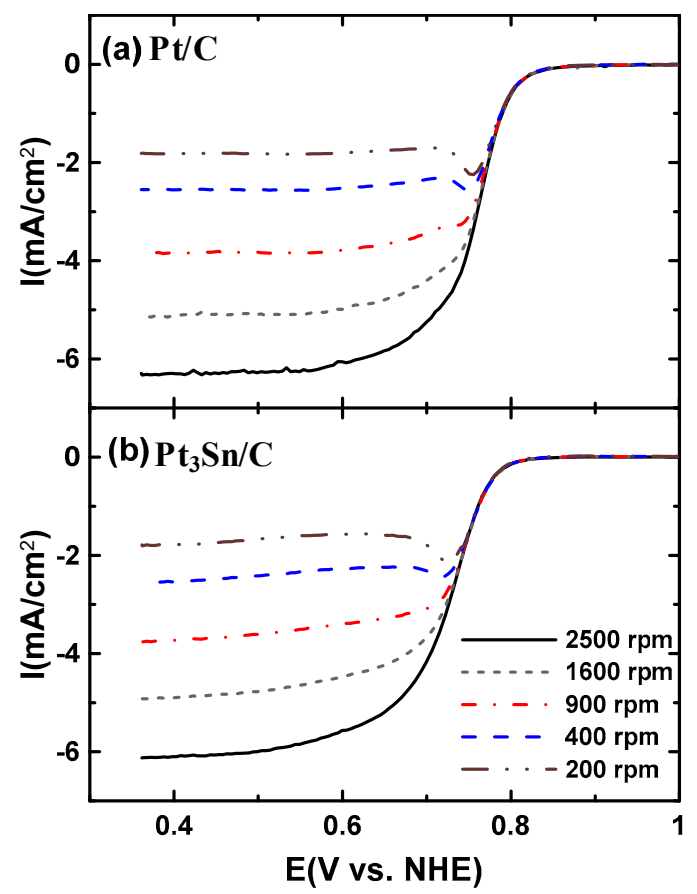

Figure 2: RRDE measurements of (a) $\mathrm{Pt} / \mathrm{C}$ (b) $\mathrm{Pt}_{3} \mathrm{Sn} / \mathrm{C}$ to study the ORR activity of the samples. Measurements were carried out in $\mathrm{O}_{2}$-saturated $0.5 \mathrm{M} \mathrm{H}_{2} \mathrm{SO}_{4}$ using different rotation rates by a scan rate of $10 \mathrm{mV} / \mathrm{s}$.

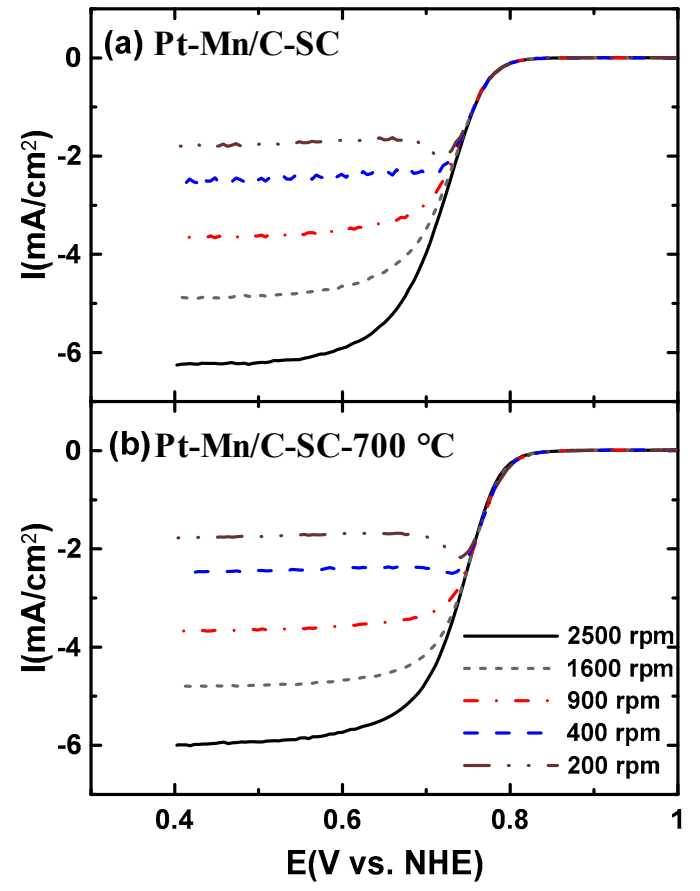

Figure 3: RRDE measurements of (a) Pt-Mn/C-SC (b) Pt-Mn/C-SC-700 ${ }^{\circ} \mathrm{C}$ to study the ORR activity of the samples. Measurements were carried out in $\mathrm{O}_{2}$-saturated $0.5 \mathrm{M} \mathrm{H}_{2} \mathrm{SO}_{4}$ using different rotation rates by a scan rate of $10 \mathrm{mV} / \mathrm{s}$. 


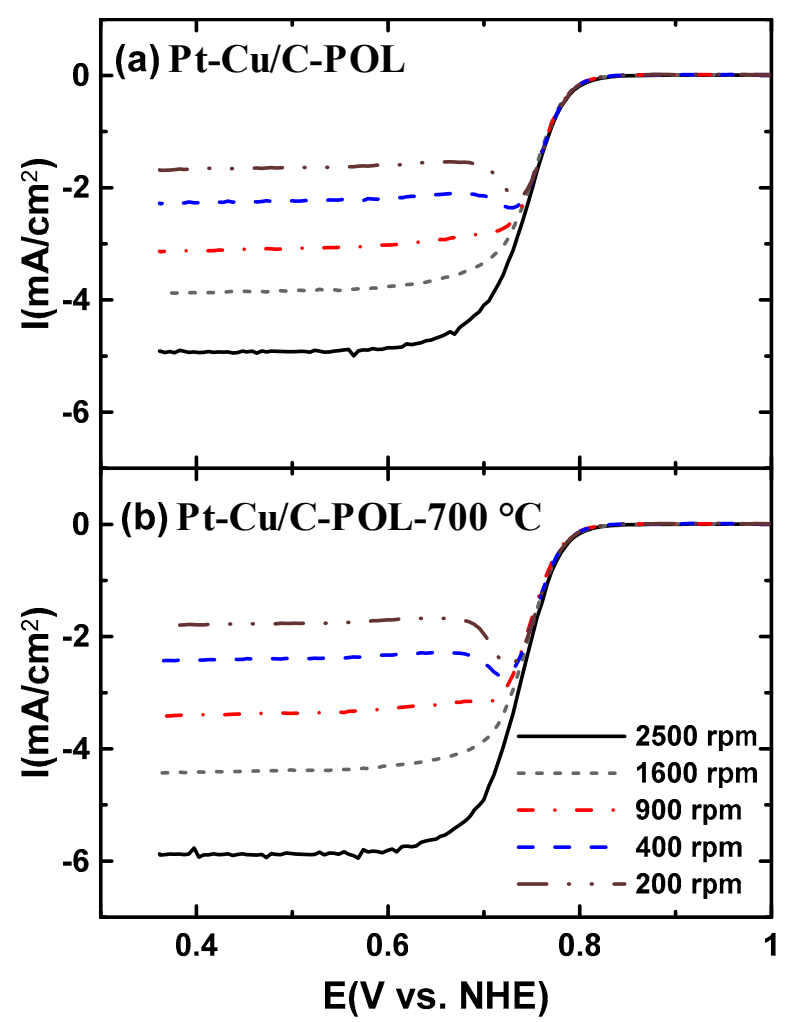

Figure 4: RRDE measurements of (a) Pt-Cu/C-POL and (b) $\mathrm{Pt}-\mathrm{Cu} / \mathrm{C}-\mathrm{POL}-700{ }^{\circ} \mathrm{C}$ to study the ORR activity of the samples. Measurements were carried out in $\mathrm{O}_{2}$-saturated $0.5 \mathrm{M} \mathrm{H}_{2} \mathrm{SO}_{4}$ using different rotation rates by a scan rate of $10 \mathrm{mV} / \mathrm{s}$.

The ORR activity of Pt-Mn/C-SC and Pt-Mn/C-SC-700 ${ }^{\circ} \mathrm{C}$ are compared in Figure 2. The $\mathrm{V}_{\text {on-set }}$ and $\mathrm{j}_{\mathrm{L}}$ of the samples were measured at $1600 \mathrm{rpm}$ and reported in Table 1. These results illustrate that the heat treatment had no effect on $\mathrm{j}$, but it shifted $\mathrm{V}_{\text {on-set }}$ to higher potential and improved the ORR activity for Pt-Mn/C-SC-700 ${ }^{\circ} \mathrm{C}$. These results indicate that during the heat treatment although there were particle enlargement and ECSA loss, the ORR activity was slightly improved in the opposite of what was expected.

The slope of the K-L plot for the Pt-Mn/C-SC and Pt-Mn/C-SC-700 ${ }^{\circ} \mathrm{C}$ samples was very close to the 4-electron reaction. This implies that the alloying of Pt with $\mathrm{Mn}$ did not changed the mechanism of the oxygen reduction. The slope of the K-L plot was changed slightly after the heat treatment. Heat treatment has been shown to change the structure of the Pt-Mn alloys and form an ordered intermetallic PtMn phase. The structural modification was the reason for the increase in the ethanol oxidation activity of the Pt-Mn alloys. 
Table 1: The on-set potential $\left(\mathrm{V}_{\text {on-set }}\right)$ and limiting current density $\left(\mathrm{j}_{\mathrm{L}}\right)$ calculated from Figure 2 and Figure 5 and the slope of Koutecky-Levich plot measured using Figure 5.

\begin{tabular}{|c|c|c|c|}
\hline Samples & $V_{\text {on-set }}(\mathrm{mV})$ at $1600 \mathrm{rpm}$ & $\mathrm{j}_{\mathrm{L}}\left(\mathrm{mA} / \mathrm{cm}^{2}\right)$ at $1600 \mathrm{rpm}$ & $\beta^{-1}$ \\
\hline $\mathrm{Pt} / \mathrm{C}$ & 821.0 & 5.12 & 2.53 \\
\hline $\mathrm{Pt}_{3} \mathrm{Sn} / \mathrm{C}$ & 791.2 & 4.92 & 2.56 \\
\hline Pt-Mn/C-SC & 786.2 & 4.89 & 2.58 \\
\hline $\mathrm{Pt}-\mathrm{Mn} / \mathrm{C}-\mathrm{SC}-700^{\circ} \mathrm{C}$ & 801.5 & 4.81 & 2.60 \\
\hline Pt-Cu/C-POL & 795.9 & 3.90 & 2.86 \\
\hline Pt-Mn/C-POL-700 ${ }^{\circ} \mathrm{C}$ & 790.9 & 4.43 & 2.63 \\
\hline
\end{tabular}

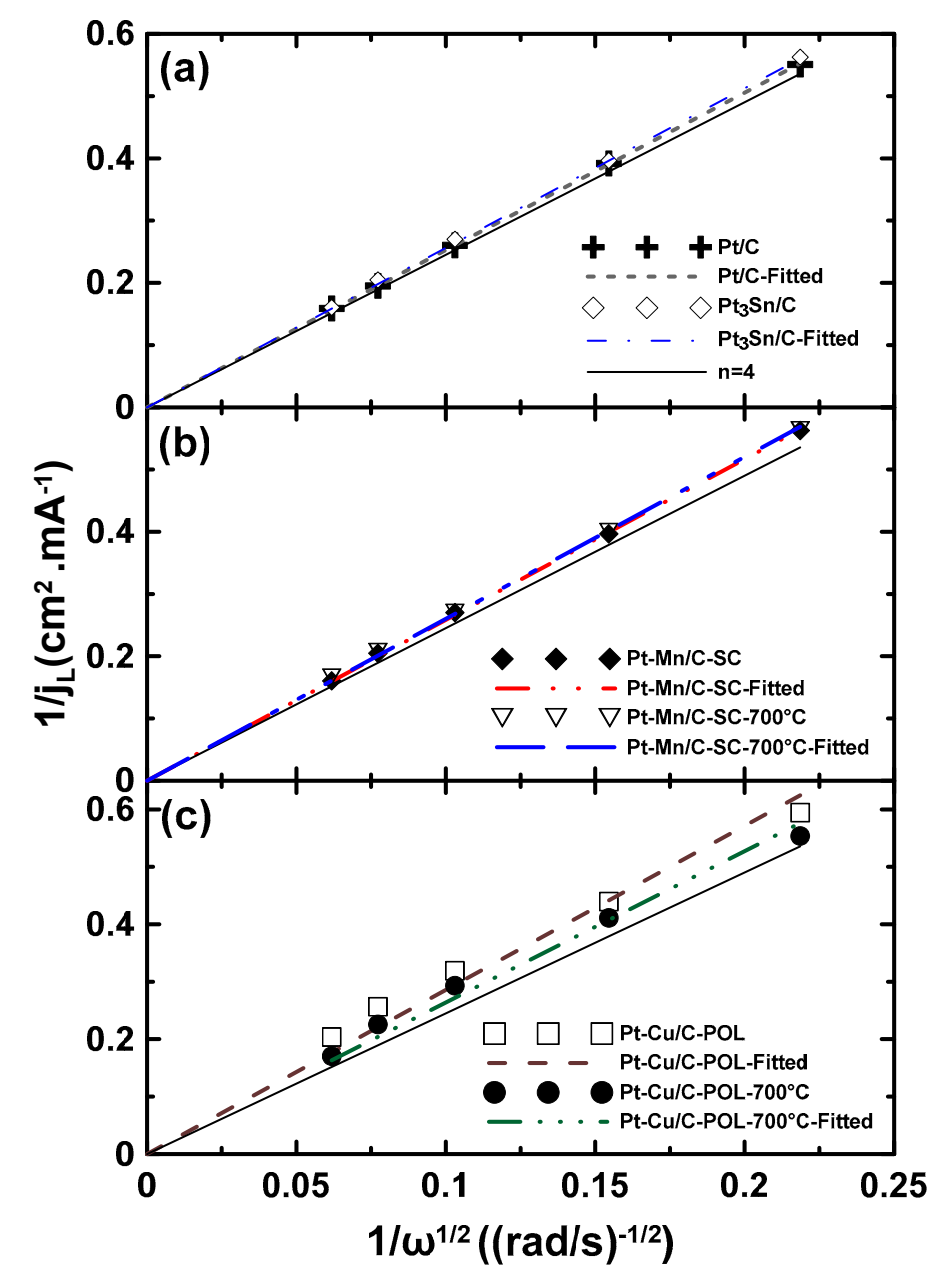

Figure 5: Koutecky-Levich plot for different samples (a) $\mathrm{Pt} / \mathrm{C}$ and $\mathrm{Pt}_{3} \mathrm{Sn} / \mathrm{C}$ (b) $\mathrm{Pt}-\mathrm{Mn} / \mathrm{C}-\mathrm{SC}$ and $\mathrm{Pt}-\mathrm{Mn} / \mathrm{C}-\mathrm{SC}-700{ }^{\circ} \mathrm{C}$ (C) Pt-Cu/C-POL and Pt-Mn/C-POL-700 ${ }^{\circ} \mathrm{C}$ which were determined using Figures 2, 3 and 4 . 
The ORR activity of the Pt-Mn alloys compared to the commercial samples (Figure 7) shows that the $\mathrm{V}_{\text {on-set }}$ was close to but slightly lower than $\mathrm{Pt} / \mathrm{C}$ even after the heat treatment. However, the $\mathrm{Pt}$ loading has reduced to almost third of the commercial sample $(\mathrm{Pt} / \mathrm{C})$ due to alloying $\mathrm{Pt}$ with Mn. Therefore, the Pt-Mn alloys can be a good candidate to replace the Pt/C catalyst in the cathode side from cost point of view in the sensor application.

In Figure 4, the ORR activity of Pt-Cu/C-POL and Pt-Cu/C-POL- $700{ }^{\circ} \mathrm{C}$ are compared. The results in Table 1 for these samples indicates that $\mathrm{V}_{\text {on-set }}$ was not changed during the heat treatment. The heat treatment resulted in larger particles which could have reduced $V_{\text {on-set, }}$ but $\mathrm{V}_{\text {on-set }}$ of the Pt-Cu alloy was not affected. This could be due to the formation of active phases during the heat treatment. It can be concluded that the formation of the ordered phases compensates the ECSA loss. This has been seen for Pt-Mn samples as well. However, jL was improved a lot by applying the heat treatment. The Pt-Cu samples were produced by the polyol method and the samples were washed very carefully to remove the ethylene glycol after synthesizing. However, a trace of ethylene glycol evaporation was detected by the TGA analysis in argon atmosphere which could be removed by the heat treatment. In Figure 6, it is possible to observe the intensity of the cracks which occurred before and after heat treatment on the surface of the deposited electrodes. The number and severity of the cracks after the heat treatment were reduced which could be due to the removal of contamination from the catalyst particles. Formation of the cracks and delamination of the catalyst layer deposited on the GC electrodes affected the smoothness of the deposits. As a result, the limiting current was altered for the samples before and after heat treatment. The improvement of $j \mathrm{~L}$ was due to the removing of the residual of ethylene glycol and improvement of the smoothness of the deposit on the GC electrodes. However, the smoothness of the samples was not as prefect as the $\mathrm{Pt} / \mathrm{C}$ and Pt-Mn samples. Therefore, jL was slightly lower than other samples even after the heat treatment. Studies on the slope of K-L plots of Pt-Cu samples show that the heat treatment also improved the slope of the plot and the mechanism of ORR was shifted more toward the 4 electron reaction. The K-L plot also shows that higher roughness on the surface of electrodes caused the plot for $\mathrm{Pt}-\mathrm{Cu} / \mathrm{C}-\mathrm{POL}$ shifted parallel to the direction of the current axis and the intersection of plot was changed which was improved after the heat treatment.

The ORR activity of the Pt-Cu alloys are also comparable to commercial samples (Figure 7). $\mathrm{V}_{\text {on-set }}$ and $\mathrm{j}_{\mathrm{L}}$ were reduced a little after the alloying of Pt with $\mathrm{Cu}$. Similar results also observed 
for Pt-Mn and Pt-Sn samples. This shows that the Pt-Cu alloys after the heat treatment can be a good choice for ORR in the sensor application.
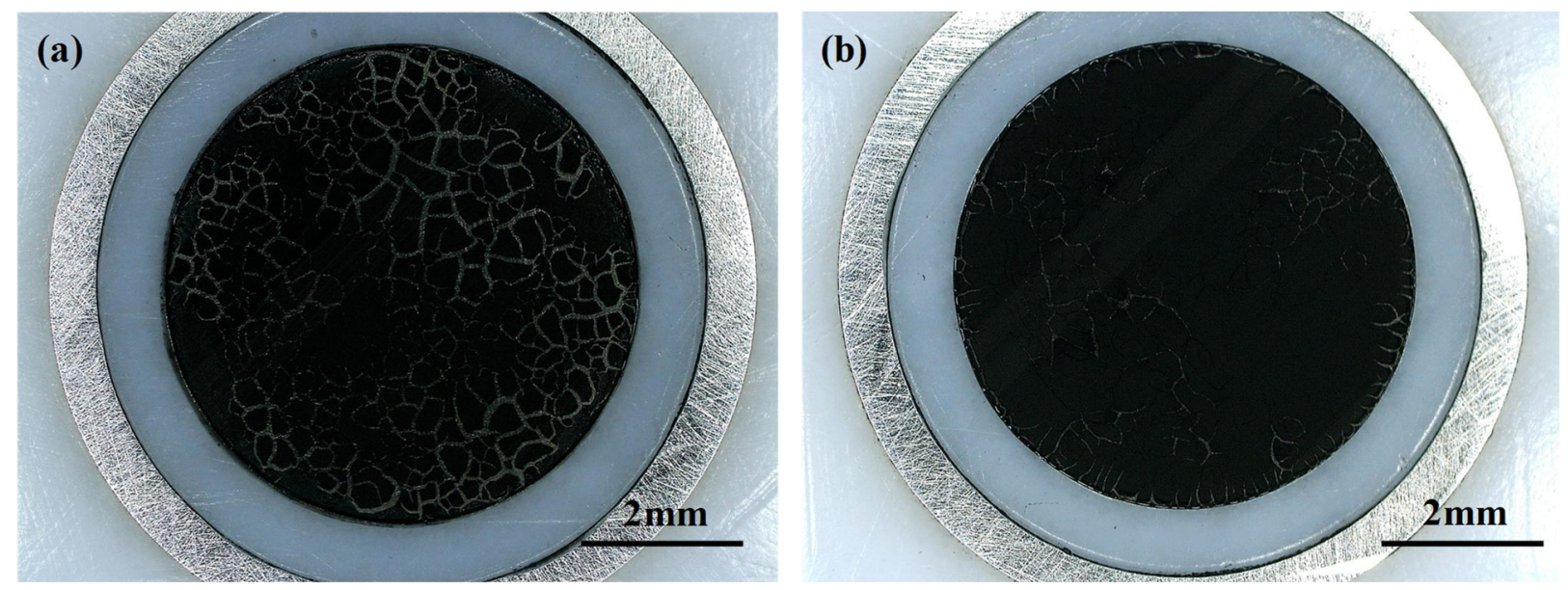

Figure 6. The cracks and delamination of the catalyst layer deposited on the GC electrode for Pt-Cu samples (a) before and (b) after heat treatment.

In Figure 7, different samples are compared at two different rotating speeds. The results indicate that the behaviour of the samples which was seen at $1600 \mathrm{rpm}$ were reproducible at 900 rpm as well. In this figure it is easier to compare $V_{\text {on-set }}$ and $j_{L}$. The highest $V_{\text {on-set }}$ and $j_{L}$ were achieved for Pt/C and the heat treatment improved $\mathrm{V}_{\text {on-set }}$ and j $\mathrm{L}$ for Pt-Mn/C-SC and Pt-Cu/CPOL, respectively. In general, it can be concluded that the alloyed samples after the heat treatment are good candidates to be utilized in the cathode side of MEA to reduce the price of sensors in the cost of losing very small ORR activity. However, the behaviour of these samples should be further studied in a real fuel cell to confirm the half-cell results.

\section{Conclusions}

The selected Pt-Mn and Pt-Cu alloys were examined for the ORR activity. The ORR activity of these alloys has also compared to the $\mathrm{Pt} / \mathrm{C}$ and $\mathrm{Pt}-\mathrm{Sn} / \mathrm{C}$ commercial samples. Finally, the effects of heat treatment and formation of ordered structures on the ORR activity in both Pt-Cu and PtMn systems were investigated. It is difficult to compare the ORR results achieved by different groups due to diverse sample production methods and catalyst layer deposition process on GC electrodes. There are limited number of studies on the Pt-Mn systems but comparing the Pt-Cu systems shows that the $\mathrm{V}_{\text {on-set }}$ reported here are slightly lower than the ones reported in other 


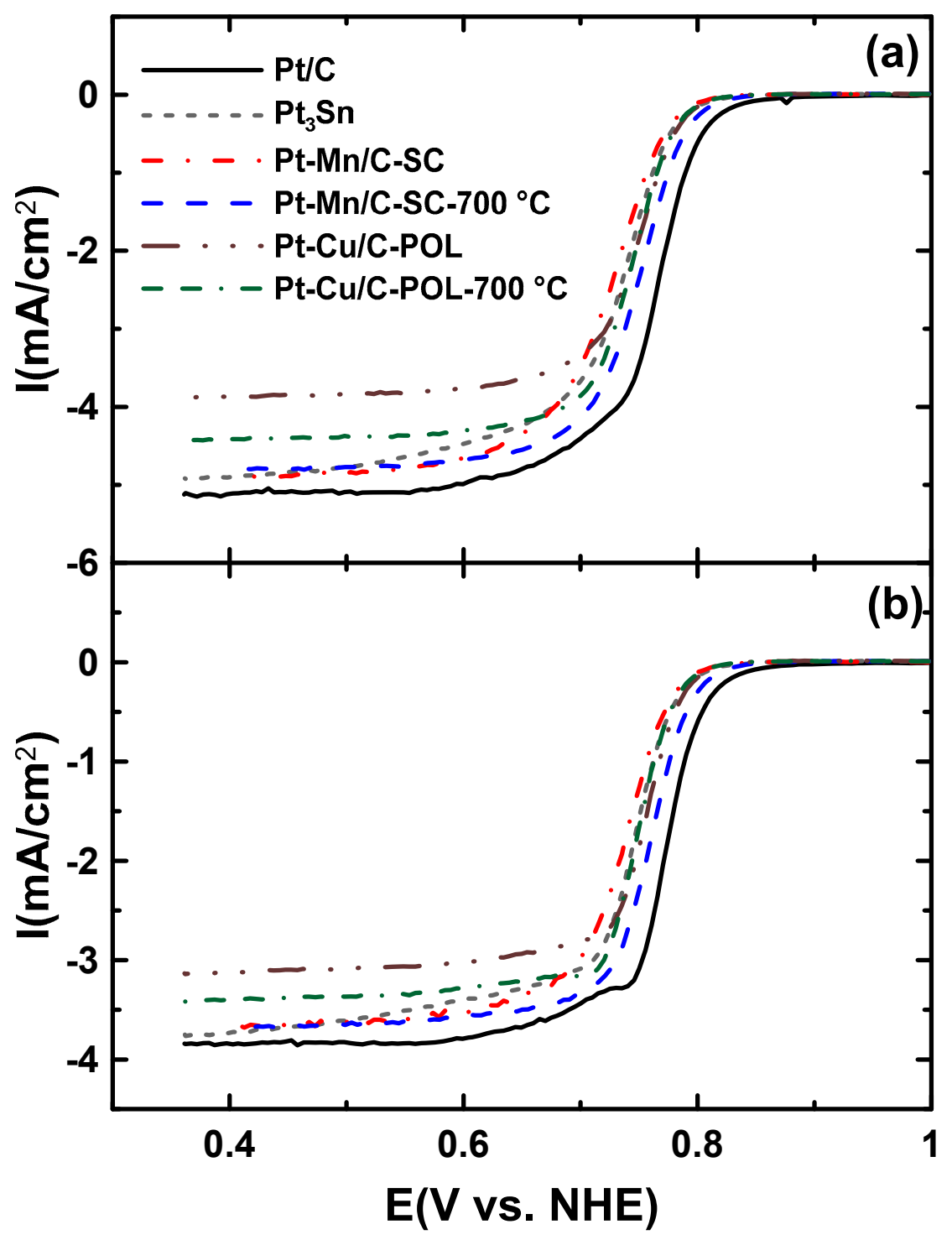

Figure 7: Comparison of the ORR activities of different samples. Measurements were carried out in $\mathrm{O}_{2}$-saturated $0.5 \mathrm{M} \mathrm{H}_{2} \mathrm{SO}_{4}$ at a scan rate of $10 \mathrm{mV} / \mathrm{s}$ using an electrode rotation rate of (a) 1600 RPM and (b) 900 RPM.

articles. One of the reasons could be due to different strategies used to report the ORR activity. Some groups used LSVs in which the potential was scanned from lower potentials to higher potentials and some others reported the opposite direction. There could be slight changes in Vonset, depends on which direction was chosen for recording LSV. On the other hand, the carbon black could introduce background to LSV responses. Here the background assigned to carbon particles by subtracting the respond in the absence of oxygen from the respond in the presence of oxygen. This could also be one of the reasons to determine lower $\mathrm{V}_{\text {on-set }}$ for the Pt-Cu samples. Finally, the 
thickness of the catalysts layer on GC could also affect the ORR respond. However, the process was kept same for all the samples reported here and commercial samples $\left(\mathrm{Pt} / \mathrm{C}\right.$ and $\left.\mathrm{Pt}_{3} \mathrm{Sn} / \mathrm{C}\right)$ was used as controlled samples. The activity of samples made in-house were compared to the commercial samples.

The studies show that the ECSA values were decreased due to the presence of alloying elements and the ESCA loss reduced $\mathrm{V}_{\text {on-set. }}$ The highest $\mathrm{V}_{\text {on-set }}$ was recorded for Pt/C. Therefore, adding the alloying elements may slightly reduce the ORR activity but resulted in catalysts with a very low Pt content which is very important from cost stand point. In addition, our findings show that the heat treatment and formation of ordered phases had a great impact on the ORR activity of the alloyed samples. It was expected after the heat treatment due to ECSA loss, $\mathrm{V}_{\text {on-set }}$ would be reduced but $\mathrm{V}_{\text {on-set }}$ for the Pt-Mn system was improved, and $\mathrm{V}_{\text {on-set }}$ for the Pt-Cu system did not change after the heat treatment. As well, the limiting current density for Pt-Mn was unchanged and it was improved for the Pt-Cu system due to removal of the contamination and improving the catalyst layer deposition on the GC electrode. Finally, the limiting current density of commercial samples and Pt-Mn samples were almost the same and they were close to theoretical values.

\section{Acknowledgements}

This work was supported by the Natural Sciences and Engineering Research Council (NSERC) of Canada through the Discovery Grant program (RGPIN-2015-003652) and Ontario Tech University. The authors acknowledge equipment support from the Canada Foundation for Innovation.

\section{References}

[1] C.W. Bezerra, L. Zhang, H. Liu, K. Lee, A.L. Marques, E.P. Marques, H. Wang, J. Zhang, Journal of Power Sources, 173 (2007) 891-908.

[2] V.R. Stamenkovic, B.S. Mun, M. Arenz, K.J. Mayrhofer, C.A. Lucas, G. Wang, P.N. Ross, N.M. Markovic, Nature materials, 6 (2007) 241-247.

[3] H.A. Gasteiger, S.S. Kocha, B. Sompalli, F.T. Wagner, Applied Catalysis B: Environmental, 56 (2005) 9-35.

[4] U. Paulus, T. Schmidt, H. Gasteiger, R. Behm, Journal of Electroanalytical Chemistry, 495 (2001) 134-145.

[5] D. Thompsett, Pt alloys as oxygen reduction catalysts, in: Handbook of Fuel Cells, John Wiley \& Sons, Ltd, 2010. 
[6] N. Markovic, T. Schmidt, V. Stamenkovic, P. Ross, FUEL CELLS-WEINHEIM-, 1 (2001) 105-116.

[7] H. Liu, C. Song, L. Zhang, J. Zhang, H. Wang, D.P. Wilkinson, Journal of Power Sources, 155 (2006) 95-110.

[8] Y. Nie, L. Li, Z. Wei, Chemical Society Reviews, 44 (2015) 2168-2201.

[9] Y. Xu, B. Zhang, Chemical Society Reviews, 43 (2014) 2439-2450.

[10] S. Zhang, X.-Z. Yuan, J.N.C. Hin, H. Wang, K.A. Friedrich, M. Schulze, Journal of Power Sources, 194 (2009) 588-600.

[11] E. Antolini, Materials Chemistry and Physics, 78 (2003) 563-573.

[12] A. Rabis, P. Rodriguez, T.J. Schmidt, ACS Catalysis, 2 (2012) 864-890.

[13] T. Ghosh, B.M. Leonard, Q. Zhou, F.J. DiSalvo, Chemistry of Materials, 22 (2010) 21902202.

[14] W. Vielstich, A. Lamm, H.A. Gasteiger, Handbook of Fuel Cells: Fundamental, Technology, and Applications, Wiley, 2003.

[15] S.G. Mavilla, B.J. MacLean, E.B. Easton, ECS Transactions, 53 (2013) 31-41.

[16] A.D. Pauric, A.W. Pedersen, T. Andrusiak, E.B. Easton, Journal of the Electrochemical Society, 157 (2010) B370-B375.

[17] A.B. Anderson, J.m. Roques, S. Mukerjee, V.S. Murthi, N.M. Markovic, V. Stamenkovic, The Journal of Physical Chemistry B, 109 (2005) 1198-1203.

[18] B.C. Beard, P.N. Ross, Journal of the Electrochemical Society, 137 (1990) 3368-3374.

[19] S. Beyhan, N.E. Şahin, S. Pronier, J.-M. Léger, F. Kadırgan, Electrochimica Acta, 151 (2015) 565-573.

[20] P. Mani, R. Srivastava, P. Strasser, Journal of Power Sources, 196 (2011) 666-673.

[21] S. Mukerjee, S. Srinivasan, Journal of Electroanalytical Chemistry, 357 (1993) 201-224.

[22] L. Xiong, A. Manthiram, Journal of The Electrochemical Society, 152 (2005) A697-A703.

[23] Z. Xu, H. Zhang, S. Liu, B. Zhang, H. Zhong, D.S. Su, International Journal of Hydrogen Energy, 37 (2012) 17978-17983.

[24] T.-H. Yeh, C.-W. Liu, H.-S. Chen, K.-W. Wang, Electrochemistry Communications, 31 (2013) $125-128$.

[25] Y.-W. Lee, S. Cha, K.-W. Park, J.I. Sohn, J.M. Kim, Journal of Nanomaterials, 2015 (2015) $1-20$.

[26] E.B. Easton, R. Yang, A. Bonakdarpour, J. Dahn, Electrochemical and solid-state letters, 10 (2007) B6-B10.

[27] N. Hodnik, C. Jeyabharathi, J.C. Meier, A. Kostka, K.L. Phani, A. Recnik, M. Bele, S. Hocevar, M. Gaberscek, K.J.J. Mayrhofer, Physical Chemistry Chemical Physics, 16 (2014) 13610-13615.

[28] A. Ignaszak, C. Teo, S. Ye, E. Gyenge, The Journal of Physical Chemistry C, 114 (2010) 16488-16504.

[29] G. Samjeské, S.-i. Nagamatsu, S. Takao, K. Nagasawa, Y. Imaizumi, O. Sekizawa, T.

Yamamoto, Y. Uemura, T. Uruga, Y. Iwasawa, Physical Chemistry Chemical Physics, 15 (2013) 17208-17218.

[30] C.-J. Tseng, S.-T. Lo, S.-C. Lo, P.P. Chu, Materials Chemistry and Physics, 100 (2006) 385390.

[31] S. Mukerjee, S. Srinivasan, M.P. Soriaga, J. McBreen, Journal of The Electrochemical Society, 142 (1995) 1409-1422. 
[32] B.-J. Su, K.-W. Wang, T.-C. Cheng, C.-J. Tseng, Materials Chemistry and Physics, 135 (2012) 395-400.

[33] J. Sun, J. Shi, J. Xu, X. Chen, Z. Zhang, Z. Peng, Journal of Power Sources, 279 (2015) 334-344.

[34] H. El-Deeb, M. Bron, Electrochimica Acta, 164 (2015) 315-322.

[35] M. Ammam, L.E. Prest, A.D. Pauric, E.B. Easton, Journal of The Electrochemical Society, 159 (2011) B195-B200.

[36] M. Ammam, E.B. Easton, Journal of The Electrochemical Society, 159 (2012) B635-B640.

[37] M. Ammam, E.B. Easton, Journal of Power Sources, 215 (2012) 188-198.

[38] M. Ammam, E.B. Easton, Journal of Power Sources, 222 (2013) 79-87.

[39] M. Ghavidel, E. Easton, Catalysts, 5 (2015) 1016.

[40] M.R. Zamanzad Ghavidel, E.B. Easton, Applied Catalysis B: Environmental, 176-177

(2015) 150-159.

[41] P. Mani, R. Srivastava, P. Strasser, The Journal of Physical Chemistry C, 112 (2008) 27702778.

[42] J.E. Harlow, D.A. Stevens, R.J. Sanderson, G.C.-K. Liu, L.B. Lohstreter, G.D. Vernstrom, R.T. Atanasoski, M.K. Debe, J.R. Dahn, Journal of The Electrochemical Society, 159 (2012) B670-B676.

[43] R. Lin, T. Zhao, M. Shang, J. Wang, W. Tang, V.E. Guterman, J. Ma, Journal of Power Sources, 293 (2015) 274-282.

[44] M.R. Zamanzad Ghavidel, A.H.A. Monteverde Videla, S. Specchia, E.B. Easton, Electrochimica Acta, 230 (2017) 58-72.

[45] M. Zamanzad Ghavidel, E.B. Easton, Catalysts, 5 (2015) 1016-1033.

[46] X. Zhang, D. Li, D. Dong, H. Wang, P.A. Webley, Materials Letters, 64 (2010) 1169-1172.

[47] M. Oezaslan, M. Heggen, P. Strasser, Journal of the American Chemical Society, 134 (2012) 514-524.

[48] M. Huang, L. Guan, International Journal of Hydrogen Energy, 40 (2015) 6546-6551.

[49] K.H. Kangasniemi, D. Condit, T. Jarvi, Journal of The Electrochemical Society, 151 (2004) E125-E132.

[50] O.A. Baturina, S.R. Aubuchon, K.J. Wynne, Chemistry of Materials, 18 (2006) 1498-1504. 